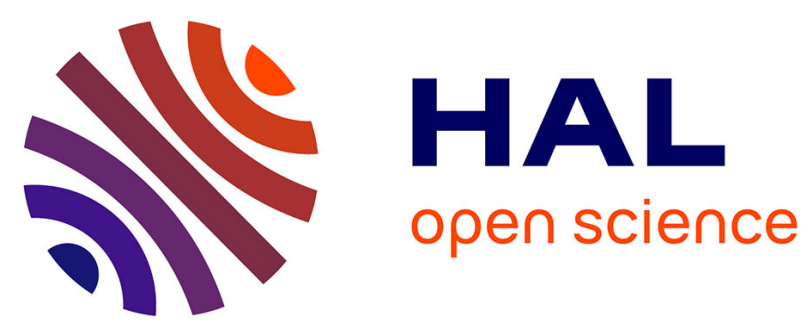

\title{
Multidrug-resistant Pseudomonas aeruginosa and mortality inmechanically ventilated ICU patients
}

Jean-Baptiste Denis, Samuel Lehingue, Vanessa Pauly, Nadim Cassir, Marc

Gainnier, Marc Léone, Florence Daviet, Benjamin Coiffard, Sophie Baron, Jean-Marie Forel, et al.

\section{To cite this version:}

Jean-Baptiste Denis, Samuel Lehingue, Vanessa Pauly, Nadim Cassir, Marc Gainnier, et al.. Multidrug-resistant Pseudomonas aeruginosa and mortality inmechanically ventilated ICU patients. American Journal of Infection Control, 2019, 10.1016/j.ajic.2019.02.030 hal-02159275

\section{HAL Id: hal-02159275 \\ https://hal-amu.archives-ouvertes.fr/hal-02159275}

Submitted on 18 Jun 2019

HAL is a multi-disciplinary open access archive for the deposit and dissemination of scientific research documents, whether they are published or not. The documents may come from teaching and research institutions in France or abroad, or from public or private research centers.
L'archive ouverte pluridisciplinaire HAL, est destinée au dépôt et à la diffusion de documents scientifiques de niveau recherche, publiés ou non, émanant des établissements d'enseignement et de recherche français ou étrangers, des laboratoires publics ou privés. 
archives-ouvertes

\section{Multidrug-resistant Pseudomonas aeruginosa and mortality inmechanically ventilated ICU patients}

Jean-Baptiste Denis, Samuel Lehingue, Vanessa Pauly, Nadim Cassir Phd,

Marc Gainnier Phd, Marc Eone Phd, Florence Daviet, Benjamin Coiffard, Sophie Baron, Jean-Marie Forel, et al.

\section{To cite this version:}

Jean-Baptiste Denis, Samuel Lehingue, Vanessa Pauly, Nadim Cassir Phd, Marc Gainnier Phd, et al.. Multidrug-resistant Pseudomonas aeruginosa and mortality inmechanically ventilated ICU patients. American Journal of Infection Control, Elsevier, 2019, 10.1016/j.ajic.2019.02.030 hal-02159275

\section{HAL Id: hal-02159275 \\ https://hal-amu.archives-ouvertes.fr/hal-02159275}

Submitted on 18 Jun 2019

HAL is a multi-disciplinary open access archive for the deposit and dissemination of scientific research documents, whether they are published or not. The documents may come from teaching and research institutions in France or abroad, or from public or private research centers.
L'archive ouverte pluridisciplinaire HAL, est destinée au dépôt et à la diffusion de documents scientifiques de niveau recherche, publiés ou non, émanant des établissements d'enseignement et de recherche français ou étrangers, des laboratoires publics ou privés. 


\title{
Major Article
}

\section{Multidrug-resistant Pseudomonas aeruginosa and mortality in mechanically ventilated ICU patients}

\author{
Jean-Baptiste Denis MD ${ }^{\mathrm{a}, *}$, Samuel Lehingue $\mathrm{MD}^{\mathrm{a}}$, Vanessa Pauly MD ${ }^{\mathrm{b}, \mathrm{c}}$, Nadim Cassir PhD ${ }^{\mathrm{d}}$, \\ Marc Gainnier PhD ${ }^{\mathrm{b}, \mathrm{e}}$, Marc Léone PhD ${ }^{\mathrm{f}, \mathrm{g}}$, Florence Daviet MD ${ }^{\mathrm{a}, \mathrm{b}}$, Benjamin Coiffard MD ${ }^{\mathrm{a}, \mathrm{f}}$, \\ Sophie Baron $\mathrm{MD}^{\mathrm{h}}$, Christophe Guervilly MD ${ }^{\mathrm{a}, \mathrm{b}}$, Jean-Marie Forel MD ${ }^{\mathrm{a}, \mathrm{b}}$, Antoine Roch PhD, MD ${ }^{\mathrm{a}, \mathrm{b}}$, \\ Laurent Papazian PhD, MD ${ }^{\mathrm{a}, \mathrm{b}}$
}

\footnotetext{
a Assistance Publique - Hôpitaux de Marseille, Hôpital Nord, Réanimation des Détresses Respiratoires et des Infections Sévères, Marseille, France

${ }^{\mathrm{b}}$ Aix-Marseille Université, School of Medicine - La Timone Medical Campus, CEReSS - Health Service Research and Quality of Life Center, Marseille, France

' Service d'Information Médicale, Public Health Department, La Conception Hospital, Assistance Publique - Hôpitaux de Marseille, Marseille, France

${ }^{\mathrm{d}}$ Service des Maladies Infectieuses et Tropicales, CHU Nord, chemin des Bourrely, Marseille, France

e Assistance Publique - Hôpitaux de Marseille, La Timone Hospital, Réanimation des Urgences, Marseille, France

${ }^{\mathrm{f}}$ Aix-Marseille Université, Faculté de médecine, Marseille, France

${ }^{\mathrm{g}}$ Assistance Publique - Hôpitaux de Marseille, Hôpital Nord, Réanimation Polyvalente, Marseille, France

${ }^{\mathrm{h}}$ Aix-Marseille Université, IRD, AP-HM, MEPHI, IHU-Méditerranée Infection, Faculté de Médecine et de Pharmacie, Marseille, France
}

Key Words:

Multidrug resistance

Recurrence

Ventilator-associated pneumonia

Intensive care medicine

Empirical antiobiotic

Nosocomial pneumonia

\begin{abstract}
A B S T R A C T
Background: The link between bacterial resistance and prognosis remains controversial. Predominant pathogen causing ventilator-associated pneumonia (VAP) is Pseudomonas aeruginosa $(\mathrm{Pa})$, which has increasingly become multidrug resistant (MDR). The aim of this study was to evaluate the relationship between MDR VAP $\mathrm{Pa}$ episodes and 30-day mortality.

Methods: From a longitudinal prospective French multicenter database (2010-2016), Pa VAP onset and physiological data were recorded. MDR was defined as non-susceptibility to at least 1 agent in 3 or more antimicrobial categories. To analyze if MDR episodes were associated with greater in-hospital 30-day mortality, we performed a multivariate survival analysis using the multivariate nonlinear frailty model.

Results: A total of 230 patients presented $286 \mathrm{~Pa}$ VAP. A maximum of 3 episodes per patient was observed; 73 episodes were MDR and 213 were susceptible. In the multivariate model, factors independently associated with 30-day mortality included hospitalization in the 6 months preceding the first episode (hazard ratio [HR], 2.31; 95\% confidence interval [CI], 1.50-3.60; $P=.0002)$, chronic renal failure $(\mathrm{HR}, 2.34 ; 95 \% \mathrm{CI}, 1.15$ 4.77; $P=.0196)$, and $P a$ VAP recurrence $(\mathrm{HR}, 2.29 ; 95 \% \mathrm{CI}, 1.79-4.87 ; P=.032)$. Finally, MDR Pa VAP was not associated with death (HR, $0.87 ; 95 \% \mathrm{CI} ; 0.52-1.45 ; P=.59$ ).
\end{abstract}

Conclusions: This study did not identify a relationship between the resistance profile of Pseudomonas aeruginosa and mortality.

\section{BACKGROUND}

Nosocomial pneumonia is the most frequently reported infection in intensive care units (ICUs), with mechanically ventilated patients

* Address correspondence to Jean-Baptiste DENIS, Assistance Publique - Hôpitaux de Marseille, Hôpital Nord, Réanimation des Détresses Respiratoires et des Infections Sévères, 13015, Marseille, France.

E-mail address: jean-baptiste.denis@ap-hm.fr (J.-B. Denis).

Conflicts of interest: None to report. being at the highest risk. The incidence of ventilator-associated pneumonia (VAP) ranges from $8 \%$ to $28 \%$ of mechanically ventilated patients. ${ }^{1}$ The incidence density of VAP is between 1.9 and 3.8 per 1000 ventilator-days in the United States and exceeds 18 per 1000 ventilator-days in Europe. ${ }^{2}$ These discrepancies are at least partly explained by the definition used for diagnosis. ${ }^{3}$ Pseudomonas aeruginosa $(\mathrm{Pa})$ is the most common bacteria causing VAP (along with Staphylococcus aureus), with a prevalence of $4.1 \%$ in a prospective international observational study performed in 11 countries. $^{4}$ 
The treatment of VAP related to $P a$ is challenging because of the emergence and increased incidence of antibiotic resistance. Multidrug resistance varies from country to country and can be as high as $40 \%{ }^{5}$ however, there is no definite established relationship between multidrug resistance and outcomes. Attributable mortality related to multidrug-resistant (MDR) $\mathrm{Pa}$ has not been extensively studied. A recent study ${ }^{6}$ reported that, compared to susceptible $P a$ VAP, the MDR Pa VAP adjusted risk ratio of ICU death was 1.34 (95\% CI, 0.971.87), suggesting that the impact on ICU mortality is indirect via an increased length of stay, which is consistent with the literature. ${ }^{7}$ The aim of the present study was, therefore, to evaluate the relationship between MDR Pa VAP episodes and mortality in a series of mechanically ventilated patients.

\section{METHODS}

\section{Study population and data collection}

We conducted a retrospective study in 3 ICUs from 2 French hospitals between January 2010 and December 2016. The analysis was based on records from a longitudinal prospectively collected database. The study was approved by the Commission Nationale de l'Informatique et des Libertés (CNIL \#CIL/AP-HM 2017/48).

Eligible patients were $\geq 18$ years old, were consecutively admitted to the ICU, had a diagnosis of VAP according to Infectious Diseases Society of America criteria, ${ }^{8}$ and had a microbiologic confirmation of monomicrobial Pa culture. The onset of each VAP episode was considered at the time the microbiologic sample was obtained. The following data were collected: age, sex, comorbidities, origin and reason for ICU admission, organ failure scores (Sepsis-Related Organ Failure Assessment and Simplified Acute Physiology Score II), duration of mechanical ventilation, length of ICU stay, length of hospital stay, and 30-day mortality.

Information concerning each VAP episode or recurrence was also collected, including the Sepsis-Related Organ Failure Assessment, antimicrobial treatment received, initiation of empiric antibiotic therapy (and its adequacy), delay between sampling and adequate antibiotic therapy, patterns of germ resistance, associated organ failures (septic shock, acute respiratory distress syndrome, acute kidney injury), and the absence/presence of bacteremia within the 48 hours before and/or after VAP episode diagnosis.

\section{Definitions}

The diagnosis of VAP was retained according to the Infectious Diseases Society of America definition: ${ }^{8}$ VAP refers to pneumonia that occurs more than 48 to 72 hours after endotracheal intubation. Colonization is defined by a positive respiratory microbiological sampling of $\mathrm{Pa}$ prior to VAP with no clinical, radiological, or biological signs of respiratory infection. The microbiological confirmation was obtained by bronchoalveolar lavage, quantitative culture with a threshold at $10^{4} \mathrm{CFU} / \mathrm{mL}$, or tracheal aspiration quantitative culture at a threshold of $10^{5} \mathrm{CFU} / \mathrm{mL}$. Multidrug resistance was defined as non-susceptibility to at least 1 agent in 3 or more antimicrobial categories. ${ }^{9}$

Empirical antibiotic therapy was considered when an antimicrobial regimen was administered within 24 hours of the sample for VAP diagnosis and before susceptibility was known. Antimicrobial therapy was considered adequate when the $P a$ isolate was susceptible to at least 1 of the antimicrobial agents prescribed. Recurrence was defined as the persistence or recurrence of the VAP criteria defined above, documented as $\mathrm{Pa}$ at least 2 days after the end of antibiotic therapy initiated for the previous episode. ${ }^{10}$ The main outcome was all-cause in-hospital mortality at day 30 (30-day mortality).

\section{Statistical analysis}

We first described the characteristics of the patients and the episodes. Quantitative data are presented as means \pm standard deviations (SDs) or medians (interquartile ranges [IQRs]). Qualitative data are presented as counts and percentages (\%). We then compared episodes of MDR Pa VAP to susceptible Pa episodes. To take into account correlations due to multiple episodes per subject, we performed univariate generalized mixed models with random interception. We used the PROC GLIMMIX procedure available in SAS 9.4 (SAS Institute; Cary, NC).

To analyze if MDR episodes were associated with higher in-hospital 30-day mortality, we performed a multivariate survival analysis using the multivariate nonlinear frailty model (with a gamma distribution of the frailty) of these repeated episodes of VAP, as well as a common origin (the start of the first episode) for each individual's event. The frailty model allowed us to take into account unobserved heterogeneity due to correlation of data (because of repeated episodes per subject). The subject was defined as a random effect. Thirty-day mortality was defined as the event. Patients still alive at day 30 following the start of VAP were censored, in addition to patients with a recurrence within these 30 days (with time to censoring = time to recurrence). After introducing all variables with a $P$ value $<.20$ in univariate analyses, we performed a backward selection using a threshold of .05 for statistical significance. The model was run with the PROC PHREG procedure available in SAS 9.4.

\section{RESULTS}

\section{Characteristics of the patients}

A total of 230 patients with Pa VAP were included during this 7year period. As shown in Table 1, acute respiratory failure was the leading cause of admission (53.5\%). Sixty percent of the patients were admitted from the ward. The median duration of ventilation was 25 days (IQR, 15-45). The median length of ICU stay was 34 days (IQR, 20-53), and the crude ICU mortality was 53\%. The mortality on day 30 was $22 \%$.

\section{Characteristics of the episodes of Pseudomonas aeruginosa VAP}

A maximum of 3 episodes per patient was observed. Figure 1 shows the distribution of the $286 \mathrm{~Pa}$ VAP episodes. A total of 73 episodes were MDR: 51 (22.2\%) at the first episode of VAP, 19 (40.4\%) at the second episode, and 3 (33.3\%) at the third episode; 213 episodes were susceptible: $179(77.8 \%)$ at the first episode, $28(59.9 \%)$ at the second episode, and 6 (66.7\%) at the third episode.

\section{Comparison between MDR Pa episodes of VAP and susceptible Pa episodes of VAP}

Hospitalization in the 6 months preceding the first episode of VAP due to $P a$ was more common in the MDR group $(P=.002)$ (Table 2). More patients had received antibiotics in the previous 30 days before VAP due to $P a$ in the MDR group $(P=.02)$. There were also more patients admitted from the ward $(P=.003)$, more patients presenting with cystic fibrosis $(P=.0001)$, more lung transplant recipients $(P<$ $.0001)$, more patients presenting with immunosuppression $(P=.0003)$, and more patients presenting with $P a$ colonization before $\operatorname{VAP}(P=.006)$ in the MDR group. More patients from the MDR Pa VAP group received inadequate empiric antibiotic therapy (18.4\% vs $4.7 \%$; $P=.002$ ). Finally, $P a$ VAP recurrence (second or third episode) was more common in the MDR group $(P=.018)$. 
Table 1

Characteristics of the population

\begin{tabular}{lc}
\hline Variable & Patients (N=230) \\
\hline Male gender, $\mathrm{n}(\%)$ & $164(71.3)$ \\
Age (y), median (IQR) & $60(47-69)$ \\
SAPS II, median (IQR) & $45(36-59)$ \\
SOFA, median (IQR) & $7(5-9)$ \\
Admission category, n (\%) & \\
Medicine & $134(58.3)$ \\
Emergency surgery & $46(20)$ \\
Scheduled surgery & $21(9.1)$ \\
Trauma & $29(12.6)$ \\
Origin of admission, n (\%) & \\
Direct admission & $92(40)$ \\
ICU admission cause, n (\%) & \\
Acute respiratory failure & $123(53.5)$ \\
Acute neurology failure & $41(17.8)$ \\
Septic shock & $28(12.2)$ \\
Acute heart failure & $16(7)$ \\
Other & $22(9.6)$ \\
Chronic illnesses, n (\%) & \\
Cardiovascular & $66(28.7)$ \\
Renal & $14(6.1)$ \\
Liver & $7(3)$ \\
Diabetes & $48(20.9)$ \\
COPD & $39(17)$ \\
Cystic fibrosis & $18(7.8)$ \\
Immunosuppression & $48(20.9)$ \\
Malignancies & $51(22.2)$ \\
Hospitalization in the last 6 mo, n (\%) & $94(40.9)$ \\
Antibiotic in the last 30 d, n (\%) & $67(29.1)$ \\
Pseudomonas colonization before VAP, $(\%)$ & $79(34.3)$ \\
\hline
\end{tabular}

$C O P D$, chronic obstructive pulmonary disease; $I C U$, intensive care unit; $I Q R$, interquartile range; SAPS II, Simplified Acute Physiology Score II; SOFA, Sepsis-Related Organ Failure Assessment; VAP, ventilator-associated pneumonia.

\section{Factors associated with day-30 mortality}

Among all the 286 VAP episodes, 99 led to death before recurrence within 30 days. In the univariate analysis, factors associated with 30day mortality were age, hospitalization in the 6 months preceding the first episode, use of antibiotics in the previous 30 days, chronic renal failure, and malignancies (Table 3). The absence of empiric antibiotic therapy was identified as a significant protective factor (HR, $0.41 ; 95 \% \mathrm{CI} ; 0.21-0.82 ; P=.012$ ). The factors associated with the severity of the episode were associated with an increased risk of death (septic shock, acute respiratory distress syndrome, acute kidney injury). $P a$ VAP recurrence was also associated with death (HR, 2.26; 95\% CI; $1.43-5.71 ; P=.003$ ). In the multivariate model (with resistance as a forced variable), factors independently associated with 30-day mortality were age (HR, 1.02; 95\% CI, 1.01-1.04; $P=.0064)$, hospitalization in the 6 months preceding the first episode (HR, 2.31; 95\% CI, 1.50-3.60; $P=.0002)$, chronic renal failure (HR, 2.34; 95\% CI, 1.15-4.77; $P=.0196)$, and $P a$ VAP recurrence (HR, 2.29; $95 \% \mathrm{CI}, 1.79-4.87 ; P=.032)$. In contrast, this analysis indicated that an episode of resistant $\mathrm{Pa}$ VAP was not considered a risk factor for death (HR, 0.87; 95\% CI, 0.52-1.45; $P=.60$ ).

\section{DISCUSSION}

This study showed that the resistance profile of Pseudomonas aeruginosa responsible for VAP was not associated with death. In contrast, the underlying condition of the patients at the time of VAP diagnosis was associated with death. The fact that recurrence is a factor associated with mortality shows that the more a patient worsens and remains on mechanical ventilation, the greater the risk of recurrence and death. However, the resistance of $\mathrm{Pa}$ also increases with recurrence.

In our study, we considered also as a recurrence the persistence of VAP occurring 2 days after the end of treatment. This may have included patients with unapparent resolution because of getting inappropriate antibiotic therapy from MDR Pa VAP in the previous episode; however, we did not find any link between adequacy or inadequacy of empiric antibiotic therapy and recurrence. Moreover, the analysis was adjusted on adequate/inappropriate antibiotic therapy, thus limiting the impact of potentially imbalanced groups on this factor.

In a univariate study, not having empiric antibiotherapy was a protective factor, compared to having an inadequate one (HR, 0.41; $95 \% \mathrm{CI}, 0.21-0.82 ; P=.0120)$. This can be explained by the wait-andsee strategy in less severe patients, which is based on waiting for

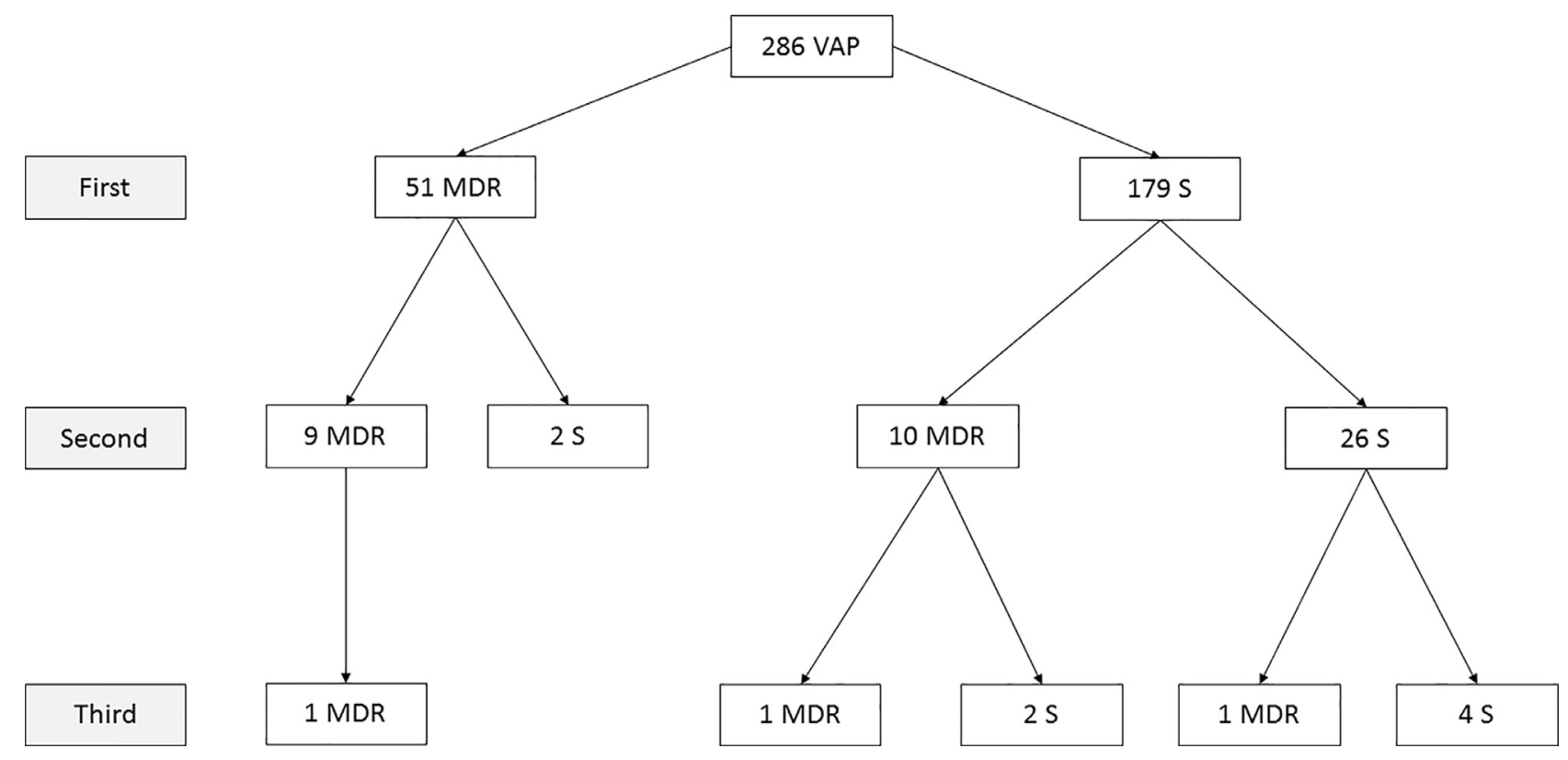

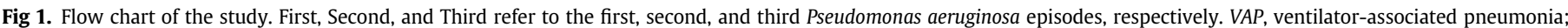
MDR, multiple drug-resistant Pseudomonas aeruginosa; S, non-MDR P aeruginosa. 
Table 2

Factors associated with MDR VAP episodes

\begin{tabular}{|c|c|c|c|}
\hline Variable & $\begin{array}{c}\text { MDR } \\
(n=73)\end{array}$ & $\begin{array}{l}\text { Susceptible } \\
(\mathrm{n}=213)\end{array}$ & $P$ value \\
\hline Male gender, n (\%) & $54(74.0)$ & $154(72.3)$ & .83 \\
\hline Age, years median (IQR) & $58(42-65)$ & $60(48-70)$ & .36 \\
\hline SAPS II, median (IQR) & $40(31-50)$ & $45(36-58)$ & .35 \\
\hline SOFA, median (IQR) & $6(4-9)$ & $6(4-9)$ & .83 \\
\hline Admission category, n (\%) & & & .06 \\
\hline Medicine & 45 (61.6) & $118(55.4)$ & \\
\hline Emergency surgery & $20(27.4)$ & $38(17.8)$ & \\
\hline Scheduled surgery & $5(6.8)$ & $22(10.3)$ & \\
\hline Trauma & $3(4.1)$ & $35(16.4)$ & \\
\hline Hospitalization in the last $6 \mathrm{mo}, \mathrm{n}(\%)$ & $41(56.2)$ & $71(33.3)$ & .003 \\
\hline Antibiotic in the last $30 \mathrm{~d}, \mathrm{n}(\%)$ & $30(41.1)$ & $52(24.4)$ & .02 \\
\hline \multicolumn{4}{|l|}{ Origin of admission, $\mathrm{n}(\%)$} \\
\hline Direct admission & $18(24.7)$ & $98(46.0)$ & .003 \\
\hline \multicolumn{4}{|l|}{ Chronic illnesses, n (\%) } \\
\hline Cardiovascular & $15(20.5)$ & $68(31.9)$ & .09 \\
\hline Kidney & $3(4.1)$ & $11(5.2)$ & .76 \\
\hline Liver & $2(2.7)$ & $6(2.8)$ & .88 \\
\hline Diabetes & $19(26.0)$ & $43(20.2)$ & .35 \\
\hline COPD & $16(21.9)$ & $32(15.0)$ & .26 \\
\hline Cystic fibrosis & $16(21.9)$ & $7(3.3)$ & $<.0001$ \\
\hline Lung transplantation & $23(31.5)$ & $20(9.4)$ & .0001 \\
\hline Immunosuppression & $29(39.7)$ & $33(15.5)$ & .0003 \\
\hline Malignancies & $13(17.8)$ & $50(23.5)$ & .36 \\
\hline Pseudomonas colonization before VAP, n (\%) & $36(49.3)$ & $63(29.6)$ & .006 \\
\hline Pseudomonas bacteremia within $48 \mathrm{~h}$ of VAP, $\mathrm{n}(\%)$ & $7(9.6)$ & $12(5.7)$ & .26 \\
\hline Septic shock within 48 h of VAP, $\mathrm{n}(\%)$ & $42(57.5)$ & $116(54.5)$ & .70 \\
\hline ARDS within $48 \mathrm{~h}$ of VAP, $\mathrm{n}(\%)$ & $50(68.5)$ & $148(69.5)$ & .95 \\
\hline AKI within $48 \mathrm{~h}$ of VAP, $\mathrm{n}(\%)$ & $20(27.4)$ & $38(17.8)$ & .14 \\
\hline Empiric antibiotic therapy, $\mathrm{n}(\%)$ & & & .002 \\
\hline Absence of empiric antibiotic therapy & $30(42.3)$ & $69(32.5)$ & \\
\hline Inadequate empiric antibiotic therapy & $13(18.3)$ & $10(4.7)$ & \\
\hline Adequate empiric antibiotic therapy & $28(39.4)$ & $133(62.7)$ & \\
\hline Adequate antibiotic therapy within $24 \mathrm{~h}, \mathrm{n}(\%)$ & $35(47.9)$ & $125(58.7)$ & .13 \\
\hline $\begin{array}{l}\text { Delay between the onset of mechanical ventilation } \\
\text { and VA (d), median (IQR) }\end{array}$ & $18(9-34)$ & $15(7-27)$ & .26 \\
\hline One or more recurrences, $\mathrm{n}(\%)$ & $22(30.14)$ & $34(16.0)$ & .018 \\
\hline
\end{tabular}

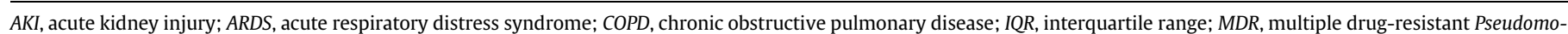
nas aeruginosa; SAPS II, Simplified Acute Physiology Score II; SOFA, Sepsis-Related Organ Failure Assessment; VAP, ventilator-associated pneumonia.

identification of the germ and antibiogram; however, this relationship was no longer found in the multivariate model.

The retrospective nature of our study is a limitation, although missing data are scarce due to prospective data capture. Interesting data such as the delay between the onset of VAP and introduction of the antibiotic treatment were not available. In the other limits of our study, we can emphasize that we have never been in a situation of therapeutic impasse.

In the literature, the risk of acquiring VAP is highest during the first 5 days of mechanical ventilation (3\%), with the mean duration between intubation and development of VAP being 3.3 days. ${ }^{11,12}$ This risk declines to $2 \%$ per day between days 5 and 10 of ventilation, and $1 \%$ per day for the remaining days. ${ }^{4}$ Chronic obstructive pulmonary disease, duration of mechanical ventilation longer than 8 days, and prior use of antibiotics are already known risk factors for $\mathrm{Pa} .{ }^{13}$

In the ICU, VAP is associated with a death rate of approximately $20 \%{ }^{7}$ however, the mortality attributable (percentage of deaths that would not have occurred in the absence of the infection) to this infection remains debated, with an estimated value between $5 \%$ and $13 \% .{ }^{14}$ One of the explanations for this huge variability is related to the difficulty of a statistical model to determine the VAP-associated mortality across many risk factors for death. Taking into account both the temporal dependence of the risk factor (VAP) and the presence of competing risks (death and discharge) by using a multistate model, Nguile-Makao et $\mathrm{al}^{15}$ reported that VAP-associated mortality was only $8.1 \%$ for a 120 -day period of observation. Being a surgical patient or having an intermediate Simplified Acute Physiology Score II score at ICU admission was associated with a higher VAP-associated mortality. These results were also reported after performing a competing risk analysis. ${ }^{14}$ VAP-associated mortality linked to $\mathrm{Pa}$ is difficult to establish clearly. A $20 \%$ increase in the risk of dying in the ICU for patients presenting VAP due to $P a$ has recently been reported. ${ }^{6}$ The authors concluded that the risk of death seems related to a decreased discharge hazard. Thus, the effect on mortality could be indirect due to a prolonged ICU stay. Our results are consistent with these conclusions; however, the advantage of our study is that it analyzes in-hospital mortality at day 30 and not only ICU mortality which allows us to eliminate a competitive risk bias. ${ }^{6}$ Moreover, considering all episodes, we made the link between mortality and recurrence, rather than resistance. Understanding the impact of $\mathrm{Pa}$ resistance on the outcome is challenging. The first reason is that there is no international consensus on the definition of multidrug resistance, which makes direct comparison of the literature difficult; however, international experts recently proposed a standardized definition of resistance. ${ }^{9}$ These resistant strains are potentially associated with inappropriate empiric antibiotic treatment, which is a main determinant of mortality in patients with pneumonia in the ICU. ${ }^{16}$ Multidrug resistance, therefore, decreases treatment options and increases the risk of delaying treatment. ${ }^{17}$ The relationship between initial antibiotic inadequacy and early mortality has already been reported, but the role of multidrug resistance remains controversial; ${ }^{18}$ therefore, it is crucial to investigate if VAP related to resistant strains of $P a$ is 
Table 3

Factors associated with day 30 in hospital mortality: univariate and multivariate frailty model

\begin{tabular}{|c|c|c|c|c|c|c|}
\hline Variable & $\begin{array}{l}\text { Survivor } \\
(\mathrm{n}=187)\end{array}$ & $\begin{array}{l}\text { 30-day deaths } \\
\quad(\mathrm{n}=99)\end{array}$ & $\begin{array}{l}\text { Univariable } \\
\text { analysis }\end{array}$ & $P$ value & $\begin{array}{c}\text { Multivariable } \\
\text { analysis }\end{array}$ & $P$ value \\
\hline Male gender, n (\%) & $141(75.4)$ & $67(67.7)$ & $0.73(0.48-1.12)$ & .15 & $0.56(0.35-0.89)$ & .013 \\
\hline Age (y), median (IQR) & $57(42-67)$ & $63(52-70)$ & $1.01(1.01-1.03)$ & .022 & $1.02(1.01-1.04)$ & .0064 \\
\hline Hospitalization in the last $6 \mathrm{mo}, \mathrm{n}(\%)$ & $57(30.5)$ & $55(55.6)$ & $2.26(1.51-3.40)$ & $<.0001$ & $2.31(1.50-3.60)$ & .0002 \\
\hline Antibiotic in the last $30 \mathrm{~d}, \mathrm{n}(\%)$ & $41(21.9)$ & $41(41.4)$ & $2.03(1.35-3.04)$ & .0006 & & \\
\hline Admission category, n (\%) & & & & .06 & & \\
\hline Medicine & $98(52.4)$ & $65(65.7)$ & $3.30(1.32-8.24)$ & & & \\
\hline Emergency surgery & $40(21.4)$ & $18(18.2)$ & $2.43(0.90-6.55)$ & & & \\
\hline Scheduled surgery & $16(8.6)$ & $11(11.1)$ & $3.57(1.21-10.53)$ & & & \\
\hline Trauma & $33(17.6)$ & $5(5.0)$ & 1 & & & \\
\hline \multicolumn{7}{|l|}{ Origin of admission, $\mathrm{n}(\%)$} \\
\hline Direct admission & $82(43.8)$ & $34(34.3)$ & $1.35(0.89-2.05)$ & .16 & & \\
\hline \multicolumn{7}{|l|}{ Chronic illnesses, n (\%) } \\
\hline Cardiovascular & $50(26.7)$ & $33(33.3)$ & $1.29(0.84-1.97)$ & .24 & & \\
\hline Kidney & $5(2.7)$ & $9(9.1)$ & $2.20(1.10-4.40)$ & .0253 & $2.34(1.15-4.77)$ & .0196 \\
\hline Liver & $3(1.6)$ & $5(5.0)$ & $2.37(0.96-5.88)$ & .06 & & \\
\hline Diabetes & $41(21.9)$ & $21(21.2)$ & $0.99(0.61-1.61)$ & .97 & & \\
\hline COPD & $28(15.0)$ & $20(20.2)$ & $1.34(0.85-2.29)$ & .18 & & \\
\hline Cystic fibrosis & $14(7.5)$ & $9(9.1)$ & $1.13(0.57-2.26)$ & .72 & & \\
\hline Lung transplantation & $29(15.5)$ & $14(14.1)$ & $0.85(0.47-1.53)$ & .58 & & \\
\hline Immunosuppression & $36(19.2)$ & $26(26.3)$ & $1.28(0.81-2.04)$ & .29 & & \\
\hline Malignancies & $30(16.0)$ & $33(33.3)$ & $1.93(1.26-2.96)$ & .0024 & & \\
\hline Pseudomonas colonization before VAP, n (\%) & $68(36.4)$ & $31(31.3)$ & $1.30(0.84-2.01)$ & .23 & & \\
\hline SAPS II, median (IQR) & $44(35-53)$ & $43(36-62)$ & $1.01(0.99-1.02)$ & .14 & & \\
\hline SOFA, median (IQR) & $5(3-8)$ & $8(6-11)$ & $1.23(1.16-1.31)$ & $<.0001$ & $1.17(1.10-1.25)$ & $<.0001$ \\
\hline $\begin{array}{l}\text { Delay between the start of mechanical } \\
\text { ventilation and VAP (d), median (IQR) }\end{array}$ & $16(8-29)$ & $12(6-28)$ & $0.99(0.98-1.00)$ & .17 & & \\
\hline Empiric antibiotic therapy, $\mathrm{n}(\%)$ & & & & .0410 & & .0386 \\
\hline Absence of empiric antibiotic therapy & $72(38.5)$ & $27(27.3)$ & $0.41(0.21-0.82)$ & .0120 & $0.61(0.30-1.25)$ & .20 \\
\hline Inadequate empiric antibiotic therapy & $10(5.3)$ & $13(13.1)$ & 1 & & 1 & \\
\hline Adequate empiric antibiotic therapy & $104(55.6)$ & $57(57.6)$ & $0.58(0.31-1.08)$ & .09 & $0.43(0.22-0.85)$ & .014 \\
\hline Effective antibiotic therapy within $24 \mathrm{~h}, \mathrm{n}(\%)$ & $101(54.0)$ & $59(59.6)$ & $1.22(0.82-1.82)$ & .34 & & \\
\hline Pseudomonas bacteremia within $48 \mathrm{~h}$ of VAP, $\mathrm{n}(\%)$ & $10(5.3)$ & $9(9.1)$ & $1.36(0.65-2.81)$ & .41 & & \\
\hline Septic shock within 48 h of VAP, n (\%) & $84(44.9)$ & $74(74.7)$ & $3.03(1.92-4.78)$ & $<.0001$ & & \\
\hline ARDS within $48 \mathrm{~h}$ of VAP, $\mathrm{n}(\%)$ & $111(59.4)$ & $87(87.9)$ & $4.13(2.25-7.57)$ & $<.0001$ & $3.46(1.78-6.79)$ & .0003 \\
\hline AKI within $48 \mathrm{~h}$ of VAP, $\mathrm{n}(\%)$ & $26(13.9)$ & $32(32.3)$ & $2.32(1.52-3.57)$ & .0001 & & \\
\hline VAP with resistant Pseudomonas, n (\%) & $45(24.1)$ & $28(28.3)$ & $1.18(0.71-1.75)$ & .63 & $0.87(0.52-1.45)$ & .60 \\
\hline One or more recurrences, $\mathrm{n}(\%)$ & $32(17.1)$ & $24(24.2)$ & $2,86(1.43-5.71)$ & .003 & $2.29(1.79-4.87)$ & .032 \\
\hline
\end{tabular}

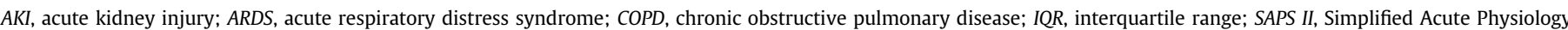
Score II; SOFA, Sepsis-Related Organ Failure Assessment; VAP, ventilator-associated pneumonia.

associated with an increased risk of death compared to more susceptible strains. The absence of a difference would indicate that VAP is not a major contributing factor to ICU death and/or that Pa pathogenicity varies according to its phenotype. Another explanation would be that attributable VAP mortality is more related to the severity of the infectious episode than the antibiotic resistance itself. ${ }^{10}$ Aloush et $\mathrm{al}^{19}$ reported a non-significant increase in crude in-hospital mortality with MDR Pa colonization or infection compared with their matched control patients. A significant association with mortality was reported for MDR Pa colonization or infection when using a multivariate model (odds ratio, 4.4; $P=.04$ ) ${ }^{16}$ However, not all patients were hospitalized in the ICU, and infections and colonizations were not distinguished in the many sites that were considered (wound, bloodstream, VAP, urinary tract). The association between multidrug resistance and increased ICU length of stay has already been reported. ${ }^{1}$

The absence of a link between multiresistance and mortality allows us to evoke bacterial fitness. Fitness is defined as the ability of bacteria to adjust its metabolism to suit environmental conditions in order to survive and grow. The selection pressure exerted by antibiotics has a fitness cost. ${ }^{20}$ This study allows a clinical approach. In conclusion, our study does not find any link between the resistance profile of Pseudomonas aeruginosa and mortality. Further studies are needed to evaluate if this is reported in large prospective studies.

\section{References}

1. Klompas M, Platt R. Ventilator-associated pneumonia-the wrong quality measure for benchmarking. Ann Intern Med 2007;147:803-5.

2. Koulenti D, Tsigou E, Rello J. Nosocomial pneumonia in 27 ICUs in Europe: Perspectives from the EU-VAP/CAP study. Eur J Clin Microbiol Infect Dis 2017;36:1999-2006.

3. Skrupky LP, McConnell K, Dallas J, Kollef MH. A comparison of ventilator-associated pneumonia rates as identified according to the National Healthcare Safety Network and American College of Chest Physicians criteria. Crit Care Med 2012;40:281-4

4. Cook DJ, Walter SD, Cook RJ, Griffith LE, Guyatt GH, Leasa D, et al. Incidence of and risk factors for ventilator-associated pneumonia in critically ill patients. Ann Intern Med 1998;129:433-40.

5. Micek ST, Wunderink RG, Kollef MH, Chen C, Rello J, Chastre J, et al. An international multicenter retrospective study of Pseudomonas aeruginosa nosocomial pneumonia: Impact of multidrug resistance. Crit Care 2015;19:219.

6. von Cube MK, Timsit J-F, Sommer H, Darmon M, Schwebel C, Bailly S, et al. Relative risk and population-attributable fraction of ICU death caused by susceptible and resistant Pseudomonas aeruginosa ventilator-associated pneumonia: A competing risks approach to investigate the OUTCOMEREA database. Intensive Care Med 2018;44:1177-9.

7. Melsen WG, Rovers MM, Groenwold RHH, Bergmans DCJJ, Camus C, Bauer TT, et al Attributable mortality of ventilator-associated pneumonia: a meta-analysis of individual patient data from randomised prevention studies. Lancet Infect Dis 2013;13:665-71.

8. Kalil AC, Metersky ML, Klompas M, Muscedere J, Sweeney DA, Palmer LB, et al. Management of adults with hospital-acquired and ventilator-associated pneumonia: 2016 clinical practice guidelines by the Infectious Diseases Society of America and the American Thoracic Society. Clin Infect Dis 2016;63:e61-111. 
9. Magiorakos A-P, Srinivasan A, Carey RB, Carmeli Y, Falagas ME, Giske CG, et al Multidrug-resistant, extensively drug-resistant and pandrug-resistant bacteria: An international expert proposal for interim standard definitions for acquired resistance. Clin Microbiol Infect 2012;18:268-81.

10. Luyt C-E, Aubry A, Lu Q, Micaelo M, Bréchot N, Brossier F, et al. Imipenem, meropenem, or doripenem to treat patients with Pseudomonas aeruginosa ventilator-associated pneumonia. Antimicrob Agents Chemother 2014;58:1372-80.

11. Torres A, Niederman MS, Chastre J, Ewig S, Fernandez-Vandellos P, Hanberger $\mathrm{H}$ et al. International ERS/ESICM/ESCMID/ALAT guidelines for the management of hospital-acquired pneumonia and ventilator-associated pneumonia: Guidelines for the management of hospital-acquired pneumonia (HAP)/ventilator-associated pneumonia (VAP) of the European Respiratory Society (ERS), European Society of Intensive Care Medicine (ESICM), European Society of Clinical Microbiology and Infectious Diseases (ESCMID) and Asociación Latinoamericana del Tórax (ALAT). Eur Respir J 2017;50. https://doi.org/10.1183/13993003.00582-2017.

12. Rello J, Ollendorf DA, Oster G, Vera-Llonch M, Bellm L, Redman R, et al. Epidemiology and outcomes of ventilator-associated pneumonia in a large US database. Chest 2002; 122:2115-21.

13. Rello J, Ausina V, Ricart M, Puzo C, Quintana E, Net A, et al. Risk factors for infection by Pseudomonas aeruginosa in patients with ventilator-associated pneumonia. Intensive Care Med 1994;20:193-8.
14. Bekaert M, Timsit J-F, Vansteelandt S, Depuydt P, Vésin A, Garrouste-Orgeas M, et al. Attributable mortality of ventilator-associated pneumonia: A reappraisal using causal analysis. Am J Respir Crit Care Med 2011;184:1133-9.

15. Nguile-Makao M, Zahar J-R, Français A, Tabah A, Garrouste-Orgeas M, Allaouchiche $B$, et al. Attributable mortality of ventilator-associated pneumonia: Respective impact of main characteristics at ICU admission and VAP onset using conditional logistic regression and multi-state models. Intensive Care Med 2010;36:781-9.

16. Alvarez-Lerma F. Modification of empiric antibiotic treatment in patients with pneumonia acquired in the intensive care unit. ICU-Acquired Pneumonia Study Group. Intensive Care Med 1996;22:387-94.

17. Peña C, Gómez-Zorrilla S, Oriol I, Tubau F, Dominguez MA, Pujol M, et al. Impact of multidrug resistance on Pseudomonas aeruginosa ventilator-associated pneumonia outcome: Predictors of early and crude mortality. Eur J Clin Microbiol Infect Dis 2013;32:413-20.

18. Tumbarello M, De Pascale G, Trecarichi EM, Spanu T, Antonicelli F, Maviglia R, et al. Clinical outcomes of Pseudomonas aeruginosa pneumonia in intensive care unit patients. Intensive Care Med 2013;39:682-92.

19. Aloush V, Navon-Venezia S, Seigman-Igra Y, Cabili S, Carmeli Y. Multidrug-resistant Pseudomonas aeruginosa: Risk factors and clinical impact. Antimicrob Agents Chemother 2006;50:43-8.

20. Pope CF, McHugh TD, Gillespie SH. Methods to determine fitness in bacteria. Methods Mol Biol 2010;642:113-21. 